Received 27.02.2017 Reviewed 30.03.2017 Accepted 05.04.2017

A - study design

B - data collection

C - statistical analysis

D - data interpretation

$\mathbf{E}$ - manuscript preparation

F - literature search

\section{Using the modified scalar product approach for testing the direction of seepage through the earth-fill dam in Pieczyska}

Stanisław LACH ${ }^{\mathrm{ABCDEF} \bowtie}$, Leszek OPYRCHAL ${ }^{\mathrm{ABCDEF}}$

AGH University of Science and Technology, Faculty of Mining Surveying and Environmental Engineering, Department of Environmental Management and Protection, al. Mickiewicza 30, 30-059 Kraków, Poland; e-mail: slach@agh.edu.pl; opyrchal@agh.edu.pl

For citation: Lach S., Opyrchał L. 2017. Using the modified scalar product approach for testing the direction of seepage through the earth-fill dam in Pieczyska. Journal of Water and Land Development. No. 33 p. 89-98. DOI: 10.1515/jwld-2017-0023.

\begin{abstract}
Currently, the problems related to the development of seepage are emerging more and more frequently. For this reason, there is a constant need to improve the existing methods, and to develop new ones, for determining the direction and intensity of the development of seepage processes occurring in earth-fill dams and their foundations. The analysed earth-fill dam is located in Pieczyska in the Kujawy-Pomerania province at $49.115 \mathrm{~km}$ from the river mouth of the Brda River. The catchment area is $4.109 \mathrm{~km}^{2}$. The article aims to verify the non-invasive, non-subjective method for examining the direction of seepage through earth-fill dams using the modified scalar product approach, which allows to determine the direction and intensity of the seepage process. A proper analysis of this process can greatly reduce the repair costs (injections or other methods of sealing), and significantly increase the safety of the existing earth-fill dams. In the case of the dam in Pieczyska, in 2010-2015, the two piezometers (located on the left abutment of the dam and denoted as P15A and P60) exhibited a direct hydraulic connection with the upstream water level (the scalar product approach). For the study dam, the "source" piezometer (to which all the piezometers in its surrounding exhibited similar changes in water levels) turned out to be the piezometer P15A. This fact was confirmed both by the number of connections between the individual piezometers and the resulting system of equipotential lines for the dam.
\end{abstract}

Key words: earth-fill dams, monitoring, piezometers, safety of hydraulic structures, scalar product

\section{INTRODUCTION}

Construction Law defines a structure as any building object which is not a building or an object of small architecture, such as earth-fill structures, or hydraulic structures [Ustawa... 1994]. Earth-fill dams, which belong to the group of hydraulic structures, are built with native soil, split stone, as well as rubble. Due to stability requirements, to build earth-fill dams, large quantities of material are required. Due to their size and weight, they are the largest and heaviest of engineering structures. Earth-fill dams are designed primarily for water impounding. It is assumed that they impound water to the height of more than $15 \mathrm{~m}$, thus creating large bodies of water with a volume in excess of $15 \cdot 10^{6} \mathrm{~m}^{3}$. The purpose of water impounding is, e.g., using the resulting reservoir as storage of water to supply towns, housing estates, industrial plants, for energy production, flood protection, navigation and recreation [DEPCZYŃSKI, SZAMOWSKI 1999].

All building structures used for storage, impounding and transportation of water, are vulnerable to damage and failures. One of the direct causes of failures of hydraulic structures may be the phenomenon of seepage, improper operation of drainage equip- 
ment, or leaching of soil material from the dams or their foundations [DEPCZYŃSKI, SZAMOWSKI 1999; YUAN, ZHONG 2016]. The phenomenon of seepage is observed when the water is in a free state, fills all the pores in the soil, these pores have a size allowing water to move in them under the force of gravity or differential pressure [WIŁUN 2001].

In order to ensure the safety and reliability of hydraulic structures, constant monitoring is required [JIE et al. 2012; KLEDYŃSKI 2011a]. Continuous observation aims to assess the condition of a building structure as well as to record and predict any failures in its structure and foundation. The basic form of monitoring earth-fill dams are e.g. piezometric measurements, which allow for measuring water levels in the open standpipe piezometer or measuring water pressure in the closed standpipe piezometer. Thanks to these measurements, it is possible to control the intensity of seepage through an impounding structure and thus to assess the durability and the safety of the structure performance [KLEDYŃSKI 2011a, b]. Monitoring water levels in piezometers also allows for the identification of anomalies occurring in earth-fill dams. As far as safety of hydraulic structures is concerned, the most favorable situation is when water levels in the piezometers oscillate around a constant value. This phenomenon proves stable seepage processes occurring in the head and in the foundation of the dam. The increasing (or decreasing) trend may indicate the movement of small particles in the core or in the foundation, which eventually may lead to the local exceedance the of permissible seepage gradients, and thus lead to a situation posing a threat to the safety of the dam [MOLSKI 2012]. Thanks to systematic measurements, it is possible to effectively prevent a potential disaster using warning systems or alarms, as well as to plan modernization of the structure in advance.

One of the methods to study the direction of seepage through the earth-fill dam is the scalar product approach [OPYRCHAt et al. 2007]. This article analyzes the modification of this approach and its use for studying the directions of seepage on the example of the dam in Pieczyska.

\section{MATERIAL AND METHODS}

The Koronowo reservoir is located in the $\mathrm{Ku}$ jawy-Pomerania province. It was created by the earthfill dam built on the Brda River at $49+115 \mathrm{~km}$ from river mouth, in Pieczyska. It covers an area of approximately $15.6 \mathrm{~km}^{2}$, while its total capacity amounts to $80.6 \cdot 10^{6} \mathrm{~m}^{3}$. Table 1 demonstrates the basic parameters of the Koronowo reservoir. The accumulation of water in the reservoir is used in the hydroelectric power station located in the town of Samociążek. The plant generates power equal to $26 \mathrm{MW}$ and produces an average of $40.84 \mathrm{GWh}$ of electricity annually. The Koronowo reservoir also plays a recreational function (data of the Koronowo Hydroelectric
Power Station). The earth-fill dam in Pieczyska closes the catchment area of $4.109 \mathrm{~km}^{2}$. It impounds water to the elevation of $81.50 \mathrm{~m}$ a.s.l., and in emergency cases (e.g. failure of the power plant), to the elevation of $82.00 \mathrm{~m}$ a.s.1. The basic parameters of the Koronowo dam are presented in Table 2.

Table 1. Basic parameters of the Koronowo reservoir

\begin{tabular}{|l|c|c|}
\hline \multicolumn{1}{|c|}{ Parameter } & Unit & Value \\
\hline Normal water level & $\mathrm{m}$ a.s.l. & 81.50 \\
\hline Maximum water level & $\mathrm{m}$ a.s.l. & 82.00 \\
\hline Minimum working water level & $\mathrm{m}$ a.s.l. & 81.00 \\
\hline Retention capacity & $\mathrm{m}^{3}$ & $8.4 \cdot 10^{2}$ \\
\hline Active storage & $\mathrm{m}^{3}$ & $21.6 \cdot 10^{2}$ \\
\hline Reservoir capacity & $\mathrm{m}^{3}$ & $80.6 \cdot 10^{6}$ \\
\hline Reservoir length & $\mathrm{km}^{2}$ & 35 \\
\hline Reservoir area & $\mathrm{km}^{2}$ & 15.6 \\
\hline
\end{tabular}

Source: own elaboration based on data of the Koronowo Hydroelectric Power Station.

Table 2. Basic parameters of the Koronowo dam

\begin{tabular}{|c|c|c|}
\hline Parameter & Unit & Value \\
\hline \multicolumn{3}{|l|}{ Dam } \\
\hline Crest of dam & m a.s.l. & 84.50 \\
\hline Width of dam & $\mathrm{m}$ & 9.0 \\
\hline $\begin{array}{l}\text { Upstream slope: } \\
\text { - lower part } \\
\text { - upstream part }\end{array}$ & & $\begin{array}{l}1: 4 \\
1: 3 \\
\end{array}$ \\
\hline $\begin{array}{l}\text { Downstream slope: } \\
\text { - from the crest of dam to datum of } 80.30 \\
\text { - between datum of } 80.30 \text { and } 76.00 \\
\text { - below datum of } 76.00\end{array}$ & & $\begin{array}{l}1: 4 \\
1: 5 \\
1: 10\end{array}$ \\
\hline Height of dam & $\mathrm{m}$ & 23.5 \\
\hline Maximum body width in foundation of dam & $\mathrm{m}$ & 60.0 \\
\hline Length od dam & $\mathrm{m}$ & 340 \\
\hline \multicolumn{3}{|l|}{ Outlet works } \\
\hline $\begin{array}{l}\text { Outlet dam diameter - two wires with cross } \\
\text { sections }\end{array}$ & $\mathrm{m}$ & $3.0 \times 3.0$ \\
\hline Length (with stilling basin) & $\mathrm{m}$ & 277.3 \\
\hline Outlet slope & $\%$ & 0.35 \\
\hline Discharge of outlets & $\mathrm{m}^{3} \cdot \mathrm{s}^{-1}$ & 73.0 \\
\hline
\end{tabular}

Source: own elaboration based on data of the Koronowo Hydroelectric Power Station.

The upstream slope of the head of the dam, at the section between 84.50 and $75.00 \mathrm{~m}$ a.s.l., was secured with concrete slabs, and the downstream slope - by turfing. The Koronowo barrage is not equipped with a spillway. In the case of reservoir overfilling, the water will overflow through the land depression in the area of the eastern end of the Lake Białe.

The subsoil of the dam is layered. It is built of medium sand (MSa), fine sand (FSa) and sandy gravel (grSa), and locally of poorly permeable silty sand (grsiSa, grclSa). The body of the dam in Pieczyska was made of fine-grained and middle-grained sand using the deposition method. The dam is equipped with a two-channel, reinforced concrete bottom outlet, used to transport water from the upstream to the lower level, as well as to periodically flush the old bottom of the Brda River in Koronowo. The outlet locks in the form of double steel flat gate valves with electric 
drive are located in the gate control house. In the area of the outlet basin, behind the outlets from the channels of the bottom vent, chicanes were used for security reasons. Below the basin, the bottom and the slopes of the Brda River have been reinforced with concrete slabs with drainage holes filled with aggre- gate at the length of $130 \mathrm{~m}$ (data of the Koronowo Hydroelectric Power Station). The dam has 91 piezometers for control measurements ( 82 of them are active). Figure 1 demonstrates the distribution of the piezometers at measurement sections of the earth-fill dam in Pieczyska.

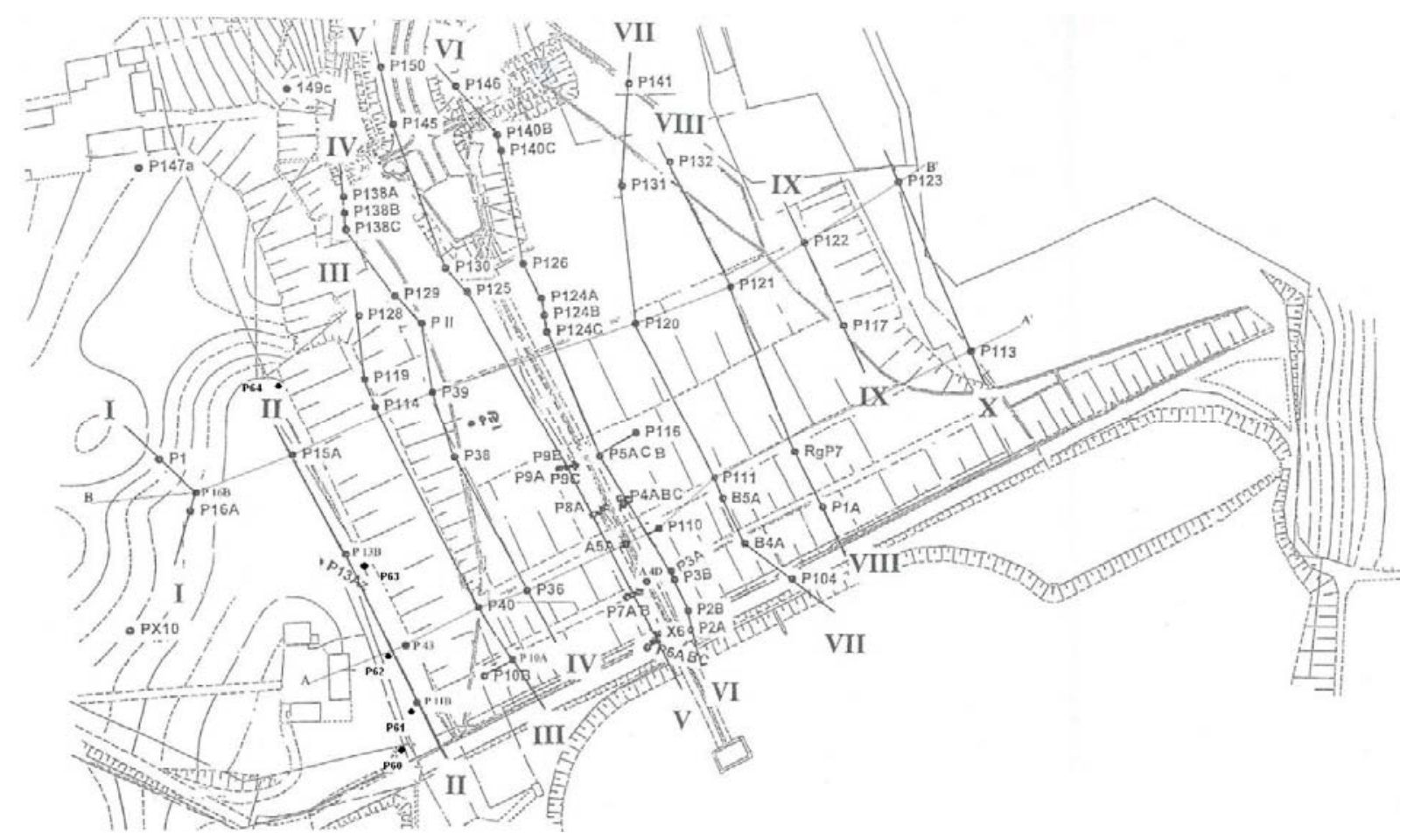

Fig. 1. Distribution of piezometers at measurement sections of the Koronowo dam; source: materials of the Koronowo Hydroelectric Power Station

The measurements of changes in the water table covering the period of six years (from 2010 to 2015) in 82 open standpipe piezometers were analyzed for the Koronowo dam. Research studies regarding the directions of seepage in earth-fill dams are carried out basing on the measurements of water levels in piezometers. Each earth-fill dam is equipped with such devices. The hydraulic contact between piezometers is confirmed on the basis of similarity in changes in water levels. Some piezometers react to the changes in the upstream or downstream water level, others react to precipitation. If the reaction to changes in the upstream water is high, it means lack of water tightness of the anti-seepage security devices, and repair of the dam is implemented [KLEDYŃSKI 2006]. This inference, however, is subjective. The research method presented in this article is largely devoid of subjectivity, as it is based on the method of quantitative analysis, which uses the scalar product approach and the selected methods of mathematical statistics. The scalar product approach is based on the following reasoning: if there is hydraulic contact between the seepage region of a specific piezometer and the upstream water level $(W G)$, then the water level in the piezometer will depend on the upstream water level. Analyzing the similarity in the course of the changes of water levels in the piezometer and changes in the upstream water level, conclusions can be drawn about the degree of hydraulic contact between the piezometer region and the upstream water level. In the scalar product approach, in order to determine the degree of similarity of changes in the water levels in the piezometer and in the upstream water level, algebraic operators and tools of mathematical analysis are used. The diagram illustrating the time series of the water levels in the analyzed piezometers is prepared in a two-dimensional continuous space, which is the Cartesian product of two closed subsets $\mathrm{R}_{+}$, one of which demonstrates the possible water levels, while the second one represents the observation period:

\section{diagram space $=$ \\ range of water levels $\cdot$ observation period}

Time series of changes in water levels in piezometers and the changes in the upstream water levels are generally smooth curves in the diagram space, and therefore, for each point of the water level curve, a tangent vector can be calculated (Fig. 2).

Let $m_{P i}\left(t_{k}\right)$ denote a vector tangent to the diagram of the course of changes in the water level in the piezometer $P_{i}$, calculated at the time $t_{k}$, and $m_{W G}\left(t_{k}\right)$ a vector tangent to the diagram of the course of changes in the upstream water level, calculated at the time $t_{k}$. This vector has the following components: 
$m_{P i}\left(t_{k}\right)=\left(t_{s}\left(t_{k}\right), w P_{i}\left(t_{k}\right)\right), m_{W G}\left(t_{k}\right)=\left(t_{s}\left(t_{k}\right), w W G\left(t_{k}\right)\right)$

where: $t_{s}=$ time component of the tangent vector at the time $t_{k}$, measured in units of time; $w P_{i}\left(t_{k}\right)=$ component of the water level in the piezometer $P_{i}$ of the tangent vector at the time $t_{k}$, measured in water impounding units; $w W G\left(t_{k}\right)=$ component of the upstream water level $W G$ of the tangential vector at the time $t_{k}$, measured in water impounding units.

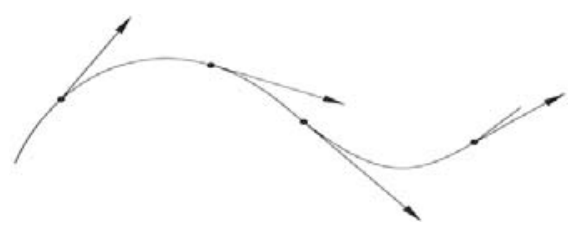

Fig. 2. Vectors tangent to the water level curve; source: own study

Let $S_{k}\left(m_{P i}\left(t_{k}\right)\right)$ denote the scalar product of the vectors $m_{P i}$ and $m_{W G}$, calculated as follows:

$$
S_{k}=\sum_{r, s=1}^{2} a_{r s} \cdot m_{P i}^{r}\left(t_{k}\right) \cdot m_{W G}^{s}\left(t_{k}\right)
$$

where: $m_{P i}^{r}=r$-th Cartesian coordinate of the vector $m_{P i}\left(t_{k}\right) ; m_{W G}^{s}=s$-th Cartesian coordinate of the vector $m_{W G} ; a_{r s}=$ components of the metric tensor.

The components of the metric tensor are calculated as follows:

$$
A=\begin{array}{cc}
\frac{1}{\left(t_{\max }-t_{\min }\right)^{2}} & 0 \\
0 & \frac{1}{\left(\max P_{i}-\min P_{i}\right)(\max W G-\min W G}
\end{array}
$$

Such a definition of the components of the metric tensor serves to unify the constituent units of the tangent vector. With the remarks made until this moment the value:

$$
C\left(P_{i}, W G\right)=\frac{\frac{1}{t_{\max }-t_{\min }} \int_{t_{\min }}^{t_{\max }} S_{k}\left(m_{P i}\left(t_{k}\right), m_{W G}\left(t_{k}\right)\right) d t}{\frac{1}{t_{\max }-t_{\min }} \int_{t_{\min }}^{t_{\max }} S_{k}\left(m_{W G}\left(t_{k}\right), m_{W G}\left(t_{k}\right)\right) d t}
$$

can be considered as a measure of similarity between the curves of the changes in water levels in the analyzed piezometer and the upstream water levels WG. In empirical practice, such curves are not continuous, but broken curves, and therefore the individual components of the tangent vectors are calculated basing on the analysis of increments between successive measurements, and the integration is replaced by summation, which results in the following formula:

$$
C\left(P_{i}, W G\right)=\frac{\sum_{t_{\min }}^{t_{\max }} S_{k}\left(m_{P i}\left(t_{k}\right), m_{W G}\left(t_{k}\right)\right)}{\sum_{t_{\min }}^{t_{\max }} S_{k}\left(m_{W G}\left(t_{k}\right), m_{W G}\left(t_{k}\right)\right)}
$$

The closer the value of $C\left(P_{i}, W G\right)$ to 1 , the better the process of the changes in the water level in the piezometer $P_{i}$ will reflect the upstream water level. From the definition we obtain $C(W G, W G)=1$.

Before performing the analysis of the piezometric data, it is necessary to remove the outliers which may significantly affect the results and cause false assessment or interpretation of the phenomenon which is subjected to this analysis [LACH 2016a; OPYRCHAt, LACH 2014]. In the case of the Koronowo dam in the period of 2010-2015, for 82 open standpipe piezometers, statistical tests demonstrated the existence of 56 outliers, which accounted for $0.20 \%$ of all the results [LACH 2016b].

In general, the theoretical distribution of the levels $C\left(P_{i}, W G\right)$ for a given piezometer is not known. For this reason, in order to determine the limit value of the measure of similarity between the water levels in the analyzed piezometers and the upstream water level above which it can be stated that there is a hydraulic contact between them, it is proposed that the values of $C\left(P_{i}, W G\right)$ are treated as implementations of a certain random variable, and then it is suggested to use the empirical distribution of the levels $C\left(P_{i}, W G\right)$ and to calculate a $95 \%$-quantile for this distribution. The quantile of order $p$ (where $0 \leq p \leq 1$ ) of the random variable $x$ is such a value of $x_{p}$ in the ascending order, which separates $p$ of the data with the values smaller than $x_{p}$ [SOBCZYK 2004]. In order to determine a quantile of any order, empirical cumulative distribution function is used, which is expressed by the following formula [NOWAK 2002]:

$\hat{F}(x)=\left\{\begin{array}{lc}0 & \text { when } x<x_{(1)}, \\ \frac{i}{n} & \text { when } x_{(i)} \leq x<x_{(i+1)}, \text { for } i=1,2, \ldots, n-1, \\ 1 & \text { when } x \geq x_{(n)}\end{array}\right.$

where $\left\{x_{(i)}\right\}_{i=1, \ldots, n}$ denotes a simple sample (a set of observations) of the variable $x$.

In the case of the measure of similarity between the water levels in the analyzed piezometers and the upstream water level, a 95\%-quantile calculated from the set of values $C\left(P_{i}, W G\right)$ allows to conclude that, statistically, $95 \%$ of the observations of the values $C\left(P_{i}, W G\right)$ adopted the value smaller than, or equal to $x_{0.95}$. Therefore, basing on the sample, it may be expected that if the similarity measure exceeds the level of $x_{0.95}$, then with the probability of at least $95 \%$ there is a statistically significant hydraulic contact between a given piezometer and the upstream water level.

In this article, using the statistical tests of Doornik-Hansen, Shapiro-Wilk, Lilliefors and Jarque-Bera, also the hypothesis was verified that the obtained similarity measures $C\left(P_{i}, W G\right)$ have a normal distribution. For the confirmation of the normal distribution of the similarity measures, the alternative definition was given of the limit value of the similarity measure, based on the use of quantiles of normal distribution. 
RESULTS AND DISCUSSION

Table 3 demonstrates collective results obtained for all the open standpipe piezometers of the Koronowo dam in the period of 2010-2015.
The first stage of the analysis of the results of similarity between the water levels in 82 open standpipe piezometers and the upstream water level (WG) involved the determination of the empirical distribution of the levels $C\left(P_{i}, W G\right)$, basing on which the fre-

Table 3. Summary of the calculations of the measure of similarity between the upstream water level and the analyzed piezometers of the Koronowo dam in control sections in the years 2010-2015

\begin{tabular}{|c|c|c|c|c|c|c|c|}
\hline $\begin{array}{l}\text { Piezometer } \\
\text { name }\end{array}$ & $\begin{array}{c}\text { Average } \\
\text { water level } \\
\text { m a.s.l. }\end{array}$ & $\begin{array}{l}\text { Standard } \\
\text { deviation } \\
\text { m a.s.l. }\end{array}$ & $\begin{array}{l}\text { Number of } \\
\text { observations } \\
\text { analysed }\end{array}$ & $\begin{array}{l}\text { Number of } \\
\text { outlier } \\
\text { observations }\end{array}$ & $\sum_{t_{\min }}^{t_{\max }} S_{k}\left(m_{P i}\left(t_{k}\right), m_{W G}\left(t_{k}\right)\right)$ & $\sum_{t_{\min }}^{t_{\max }} S_{k}\left(m_{W G}\left(t_{k}\right), m_{W G}\left(t_{k}\right)\right)$ & $\begin{array}{l}\text { Similarity } \\
\text { measures } \\
C\left(P_{i}, W G\right)\end{array}$ \\
\hline 1 & 2 & 3 & 4 & 5 & 6 & 7 & 8 \\
\hline \multicolumn{8}{|c|}{ Control section I-I } \\
\hline P1 & 69.14 & 0.18 & 313 & 0 & 0.0061 & 0.0515 & 0.1178 \\
\hline $\mathrm{P} 16 \mathrm{~A}$ & 69.44 & 0.24 & 313 & 2 & 0.0068 & 0.0326 & 0.2081 \\
\hline $\mathrm{P} 16 \mathrm{~B}$ & 78.30 & 0.24 & 313 & 3 & 0.0070 & 0.0393 & 0.1781 \\
\hline \multicolumn{8}{|c|}{ Control section II-II } \\
\hline P11B & 76.89 & 0.27 & 313 & 0 & 0.0045 & 0.0322 & 0.1385 \\
\hline $\mathrm{P} 13 \mathrm{Az}$ & 69.51 & 0.29 & 313 & 1 & 0.0051 & 0.0255 & 0.1986 \\
\hline $\mathrm{P} 13 \mathrm{~B}$ & 77.54 & 0.20 & 313 & 0 & 0.0097 & 0.0471 & 0.2059 \\
\hline $\mathrm{P} 15 \mathrm{~A}$ & 68.66 & 0.23 & 313 & 0 & 0.0071 & 0.0241 & 0.2946 \\
\hline $\mathrm{P} 43$ & 76.58 & 0.22 & 313 & 0 & 0.0052 & 0.0399 & 0.1303 \\
\hline P60 & 76.31 & 0.53 & 313 & 2 & 0.0043 & 0.0177 & 0.2429 \\
\hline \multicolumn{8}{|c|}{ Control section IIa-IIa } \\
\hline P61 & 77.30 & 0.23 & 313 & 0 & 0.0057 & 0.0410 & 0.1390 \\
\hline P62 & 77.38 & 0.24 & 313 & 0 & 0.0054 & 0.0393 & 0.1374 \\
\hline P63 & 77.42 & 0.27 & 313 & 1 & 0.0047 & 0.0407 & 0.1155 \\
\hline P64 & 78.97 & 0.13 & 313 & 4 & 0.0046 & 0.0962 & 0.0478 \\
\hline \multicolumn{8}{|c|}{ Control section III-III } \\
\hline $\mathrm{P} 10 \mathrm{~A}$ & 70.08 & 0.37 & 313 & 0 & 0.0049 & 0.0234 & 0.2094 \\
\hline P10B & 76.21 & 0.16 & 313 & 0 & 0.0075 & 0.0534 & 0.1404 \\
\hline $\mathrm{P} 40$ & 69.72 & 0.32 & 313 & 0 & 0.0048 & 0.0257 & 0.1868 \\
\hline P114 & 68.17 & 0.21 & 313 & 1 & 0.0074 & 0.0356 & 0.2079 \\
\hline P119 & 67.92 & 0.20 & 313 & 1 & 0.0031 & 0.0379 & 0.0818 \\
\hline P128 & 67.00 & 0.33 & 313 & 0 & 0.0023 & 0.0143 & 0.1608 \\
\hline \multicolumn{8}{|c|}{ Control section IV-IV } \\
\hline P36 & 69.35 & 0.31 & 313 & 1 & 0.0033 & 0.0263 & 0.1255 \\
\hline P38 & 68.20 & 0.23 & 313 & 2 & 0.0057 & 0.0289 & 0.1972 \\
\hline P39 & 67.45 & 0.25 & 313 & 0 & 0.0045 & 0.0280 & 0.1607 \\
\hline P129 & 66.90 & 0.16 & 313 & 1 & 0.0052 & 0.0426 & 0.1221 \\
\hline P138A & 65.46 & 0.15 & 313 & 2 & 0.0025 & 0.0362 & 0.0691 \\
\hline $\mathrm{P} 138 \mathrm{~B}$ & 65.39 & 0.14 & 313 & 1 & 0.0072 & 0.0487 & 0.1478 \\
\hline $\mathrm{P} 138 \mathrm{C}$ & 65.90 & 0.13 & 313 & 0 & 0.0061 & 0.0528 & 0.1155 \\
\hline PII & 67.11 & 0.16 & 313 & 1 & 0.0064 & 0.0447 & 0.1432 \\
\hline PIV & 67.85 & 0.20 & 313 & 0 & 0.0044 & 0.0359 & 0.1226 \\
\hline \multicolumn{8}{|c|}{ Control section V-V } \\
\hline A4B & 69.26 & 0.31 & 313 & 1 & 0.0039 & 0.0270 & 0.1444 \\
\hline A4D & 76.53 & 0.10 & 313 & 0 & 0.0081 & 0.0880 & 0.0920 \\
\hline P6A & 69.71 & 0.32 & 313 & 4 & 0.0054 & 0.0265 & 0.2038 \\
\hline P6B & 70.00 & 0.36 & 313 & 1 & 0.0043 & 0.0237 & 0.1814 \\
\hline $\mathrm{P} 6 \mathrm{C}$ & 69.84 & 0.36 & 313 & 0 & 0.0035 & 0.0239 & 0.1464 \\
\hline P7A & 69.37 & 0.30 & 313 & 0 & 0.0058 & 0.0277 & 0.2094 \\
\hline P7B & 69.34 & 0.32 & 313 & 0 & 0.0047 & 0.0259 & 0.1815 \\
\hline P8A & 68.63 & 0.30 & 313 & 0 & -0.0024 & 0.0260 & -0.0923 \\
\hline P8B & 68.49 & 0.27 & 313 & 0 & 0.0038 & 0.0233 & 0.1631 \\
\hline $\mathrm{P} 8 \mathrm{C}$ & 68.35 & 0.26 & 313 & 0 & 0.0050 & 0.0305 & 0.1639 \\
\hline P9A & 68.18 & 0.24 & 313 & 0 & 0.0050 & 0.0331 & 0.1511 \\
\hline P9B & 68.08 & 0.24 & 313 & 0 & 0.0040 & 0.0331 & 0.1208 \\
\hline P9C & 67.65 & 0.23 & 313 & 0 & 0.0054 & 0.0324 & 0.1667 \\
\hline P125 & 66.24 & 0.16 & 313 & 0 & 0.0076 & 0.0471 & 0.1614 \\
\hline P130 & 66.12 & 0.15 & 313 & 0 & 0.0052 & 0.0498 & 0.1044 \\
\hline P145 & 62.83 & 0.12 & 313 & 2 & 0.0018 & 0.0827 & 0.0218 \\
\hline P150 & 63.09 & 0.23 & 313 & 0 & 0.0030 & 0.0273 & 0.1099 \\
\hline $\begin{array}{l}\mathrm{X} 6 \\
\end{array}$ & 70.03 & 0.31 & 313 & 0 & 0.0037 & 0.0271 & 0.1365 \\
\hline
\end{tabular}


contin. Tab. 3

\begin{tabular}{|c|c|c|c|c|c|c|c|}
\hline 1 & 2 & 3 & 4 & 5 & 6 & 7 & 8 \\
\hline \multicolumn{8}{|c|}{ Control section VI-VI } \\
\hline P2A & 69.55 & 0.32 & 313 & 1 & 0.0041 & 0.0239 & 0.1715 \\
\hline $\mathrm{P} 2 \mathrm{~B}$ & 69.56 & 0.31 & 313 & 0 & 0.0051 & 0.0268 & 0.1903 \\
\hline $\mathrm{P} 3 \mathrm{~A}$ & 69.17 & 0.29 & 313 & 0 & 0.0056 & 0.0284 & 0.1972 \\
\hline P3B & 69.09 & 0.29 & 313 & 0 & 0.0042 & 0.0287 & 0.1463 \\
\hline $\mathrm{P} 4 \mathrm{~A}$ & 68.43 & 0.25 & 313 & 1 & 0.0028 & 0.0284 & 0.0986 \\
\hline $\mathrm{P} 4 \mathrm{~B}$ & 68.21 & 0.25 & 313 & 0 & 0.0046 & 0.0320 & 0.1438 \\
\hline $\mathrm{P} 4 \mathrm{C}$ & 68.20 & 0.24 & 313 & 0 & 0.0043 & 0.0313 & 0.1374 \\
\hline $\mathrm{P} 5 \mathrm{~A}$ & 68.04 & 0.23 & 313 & 1 & 0.0044 & 0.0333 & 0.1321 \\
\hline $\mathrm{P} 5 \mathrm{~B}$ & 68.02 & 0.23 & 313 & 0 & 0.0051 & 0.0333 & 0.1532 \\
\hline $\mathrm{P} 5 \mathrm{C}$ & 67.40 & 0.25 & 313 & 1 & 0.0027 & 0.0237 & 0.1139 \\
\hline P110 & 68.76 & 0.26 & 313 & 0 & 0.0055 & 0.0309 & 0.1780 \\
\hline P116 & 67.92 & 0.22 & 313 & 2 & 0.0047 & 0.0343 & 0.1370 \\
\hline P124A & 65.79 & 0.32 & 313 & 0 & 0.0049 & 0.0364 & 0.1346 \\
\hline P124B & 66.31 & 0.17 & 313 & 1 & 0.0055 & 0.0389 & 0.1414 \\
\hline P124C & 66.21 & 0.16 & 313 & 0 & 0.0062 & 0.0456 & 0.1360 \\
\hline $\mathrm{P} 126$ & 65.58 & 0.14 & 313 & 0 & 0.0100 & 0.0528 & 0.1894 \\
\hline P140B & 64.25 & 0.10 & 313 & 1 & 0.0044 & 0.0602 & 0.0731 \\
\hline P140C & 64.31 & 0.09 & 313 & 0 & 0.0077 & 0.0702 & 0.1097 \\
\hline P146 & 63.76 & 0.11 & 313 & 2 & 0.0073 & 0.0509 & 0.1434 \\
\hline \multicolumn{8}{|c|}{ Control section VII-VII } \\
\hline B4A & 68.78 & 0.27 & 313 & 1 & 0.0046 & 0.0307 & 0.1498 \\
\hline B5A & 68.33 & 0.25 & 313 & 0 & 0.0038 & 0.0324 & 0.1173 \\
\hline $\mathrm{P} 104$ & 69.09 & 0.29 & 313 & 2 & 0.0028 & 0.0294 & 0.0952 \\
\hline P111 & 68.30 & 0.25 & 313 & 3 & 0.0059 & 0.0298 & 0.1980 \\
\hline P120 & 66.54 & 0.18 & 313 & 1 & 0.0026 & 0.0309 & 0.0841 \\
\hline $\mathrm{P} 131$ & 65.65 & 0.14 & 313 & 2 & 0.0077 & 0.0498 & 0.1546 \\
\hline P141 & 65.07 & 0.12 & 313 & 1 & 0.0080 & 0.0628 & 0.1274 \\
\hline \multicolumn{8}{|c|}{ Control section VIII-VIII } \\
\hline $\mathrm{P} 1 \mathrm{~A}$ & 68.57 & 0.28 & 313 & 1 & 0.0048 & 0.0260 & 0.1846 \\
\hline P121 & 66.68 & 0.18 & 313 & 1 & 0.0022 & 0.0407 & 0.0541 \\
\hline P132 & 65.81 & 0.15 & 313 & 1 & 0.0033 & 0.0492 & 0.0671 \\
\hline RgP7 & 68.04 & 0.24 & 313 & 0 & 0.0043 & 0.0267 & 0.1610 \\
\hline \multicolumn{8}{|c|}{ Control section IX-IX } \\
\hline P117 & 67.38 & 0.21 & 313 & 0 & 0.0049 & 0.0386 & 0.1269 \\
\hline $\mathrm{P} 122$ & 66.89 & 0.19 & 313 & 1 & 0.0033 & 0.0410 & 0.0805 \\
\hline \multicolumn{8}{|c|}{ Control section $\mathrm{X}-\mathrm{X}$} \\
\hline P113 & 67.85 & 0.24 & 313 & 0 & 0.0045 & 0.0359 & 0.1253 \\
\hline P123 & 66.81 & 0.18 & 313 & 1 & 0.0071 & 0.0438 & 0.1621 \\
\hline \multicolumn{8}{|c|}{ Piezometers beyond control sections } \\
\hline $\mathrm{A} 5 \mathrm{~A}$ & 68.80 & 0.28 & 313 & 0 & 0.0029 & 0.0289 & 0.1003 \\
\hline S-5 & 67.25 & 0.24 & 313 & 0 & 0.0060 & 0.0345 & 0.1739 \\
\hline
\end{tabular}

Source: own study.

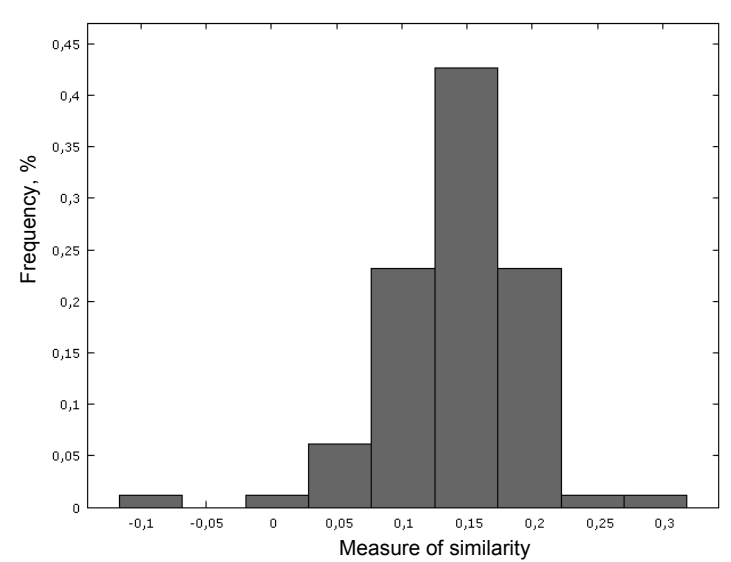

Fig. 3. Diagram of the frequency distribution of the levels $C\left(P_{i}, W G\right)$ obtained for the dam in Pieczyska in the years 2010-2015; source: own study quency distribution was plotted (Fig. 3). Statistical analysis was performed in the free software Gretl (version 1.9.90).

Measures of similarity between the water levels in the analyzed open standpipe piezometers and the upstream water level have been divided into nine intervals, for which the number and frequency of their occurrence were calculated (Tab. 4). The table clearly illustrates that the vast majority of the calculated measures of similarity (approximately $41.5 \%$ ) belongs to the sixth interval (the total of 34 results). Only one measure of similarity was below the value of $C\left(P_{i}, W G\right)=-0.068119$. On the other hand, three piezometers of the dam in Pieczyska had the levels of similarity measures above the value of $C\left(P_{i}, W G\right)=$ -0.22206 . 
Table 4. Frequency distribution of the levels $C\left(P_{i}, W G\right)$ obtained for the dam in Pieczyska in the years 2010-2015

\begin{tabular}{|c|c|c|c|}
\hline Number & Interval & Sample size & Frequency, $\%$ \\
\hline 1 & $<-0.068119$ & 1 & 1.22 \\
\hline 2 & $-0.068119-(-0.019756)$ & 0 & 0.00 \\
\hline 3 & $-0.019756-0.028606$ & 1 & 1.22 \\
\hline 4 & $0.028606-0.076969$ & 5 & 6.10 \\
\hline 5 & $0.076969-0.12533$ & 19 & 23.17 \\
\hline 6 & $0.12533-0.17369$ & 34 & 41.46 \\
\hline 7 & $0.17369-0.22206$ & 19 & 23.17 \\
\hline 8 & $0.22206-0.27042$ & 2 & 2.44 \\
\hline 9 & $\geq 0.27042$ & 1 & 1.22 \\
\hline \multicolumn{2}{r}{ Total } & $\mathbf{8 2}$ & $\mathbf{1 0 0 . 0 0}$ \\
\hline
\end{tabular}

Source: own study.

Table 5 presents the results of statistical tests studying the normality of the distribution of similarity measures $C\left(P_{i}, W G\right)$ for the analyzed dam. As the table shows, all four tests definitely rejected the $\mathrm{H} 0$ hypothesis regarding the normality of the distribution of the levels $C\left(P_{i}, W G\right)$ for the dam in Pieczyska.

Table 5. Results of statistical tests examining the normality of the distribution of similarity measures $C\left(P_{i}, W G\right)$ for the dam in Pieczyska in the years 2010-2015

\begin{tabular}{|c|l|c|c|} 
Number & \multicolumn{1}{|c|}{ Statistical test } & $\begin{array}{c}\text { Value of the test } \\
\text { statistics }\end{array}$ & $p$-value \\
\hline 1 & Doornik-Hansen & 22.82 & $1.10 \cdot 10^{-5}$ \\
2 & Shapiro-Wilk & 0.94 & 0.0014 \\
\hline 3 & Lilliefors & 0.14 & 0.000 \\
\hline 4 & Jarque-Bera & 58.22 & $2.28 \cdot 10^{-13}$ \\
\hline
\end{tabular}

Source: own study.

Then, calculations were made of the $95 \%$-quantile for the empirical distribution of the levels $C\left(P_{i}\right.$, $W G)$, which for the dam in Pieczyska in the period of 2010-2015 reached a value of 0.2108 . This result led to the conclusion that, statistically, $95 \%$ of the observations of the value $C\left(P_{i}, W G\right)$ adopted the value smaller than, or equal to 0.2108 . Therefore, on the basis of the sample, it could be stated that if the similarity measure exceeded the level of 0.2108 , then with the probability of at least $95 \%$ there was a statistically significant hydraulic contact between a given piezometer and the upstream water level. A direct hydraulic contact was identified for only two of the piezometers: P15A (the difference of 0.08376 relative to the 95\%-quantile) and P60 (the difference reaching 0.0321 relative to the calculated $95 \%$-quantile).

The relationship between fluctuations in the water levels in the analyzed piezometers of the studied dam was assessed based on the calculation of the correlation coefficients for all the piezometers, thus creating an appropriate correlation matrix [FELLER 2006; ŁOMNICKI 2014]. In order to determine whether a given correlation coefficient is statistically significant (statistically different from zero), appropriate test were carried out, assuming the test significance level equal to $\alpha=0.05$. The test statistics in the two-tailed significance test of the Pearson $r$ correlation coefficient has a Student's t-distribution with $N-2$ degrees of freedom (where $N$ is the number of observations). After determining the number of the degrees of freedom, in order to decide whether the correlation coefficient is statistically significant, the critical value of the test was read for the predetermined significance level $\alpha$ and the correct number of the degrees of freedom. If the absolute value of the correlation coefficient is greater than the critical value, this means that for a predetermined significance level, the calculated Pearson $r$ correlation coefficient is statistically significant [CZAJA, PREWEDA 2000].

All the calculations were carried out in the demo version of Matlab R2012a. A complement to the test of the statistical significance was the assumption that if the resulting correlation coefficient $r$ exceeds 0.70 , the relationship between the variables $x$ and $y$ can be regarded as strong (and due to the positive correlation it is possible to talk about the similarity of the dynamics of $x$ and $y$ ), however, in the case when $r \leq 0.3$, such a relationship should not be taken into account. If $0.3<r<0.7$, the relationship between the variables $x$ and $y$ is treated as weak, and also neglected, as in [BYCZKOWSKI 1999]. Such a criterion allowed to measure the strength of the relationship between the analyzed properties. Then, for each piezometer, the number of the cases for which $r>0.7$ was calculated, enabling to identify the "source", or the piezometer to which all the piezometers in its surrounding exhibited similar changes in water levels. The maximum correlation coefficient $r=0.9922$ occurred for a couple of piezometers $\mathrm{P} 8 \mathrm{~B}-\mathrm{P} 8 \mathrm{C}$, while the minimum correlation coefficient, which reached the value of $r=-0.4233$ was identified for a couple of piezometers P63-P150. The vast majority of the correlation coefficients turned out to be statistically significant. Statistical significance, however, does not allow to assess the degree of similarity between the analyzed values. For this reason, Table 6 demonstrates a number of relationships (i.e. the number of correlation coefficients between a given piezometer and the remaining ones exceeding the value of 0.7 ) for each of the analyzed piezometer of the earth-fill dam in Pieczyska in the years 2010-2015.

The largest number of relationships occurred for the piezometer P15A, and the lack of relationships was demonstrated for the piezometers P124 and P64. The piezometer P15A proved to be the "source", to which the other 72 piezometers $(87.8 \%)$ in its surrounding exhibited similar changes in water levels (understood as a situation in which the Pearson $r$ correlation coefficient exceeds 0.7 ). Both piezometers are located on the left abutment of the earth-fill dam in Pieczyska and they confirmed the earlier results obtained by the method of the scalar product.

The results were compared with a graphical method for studying the direction of seepage in earthfill dams, which involved drawing equipotential lines - the lines that connect points of equal hydraulic head in the aquifer. The system of equipotential lines is a map of the underground water table, thanks to which 
Table 6. Number of relationships for each analyzed piezometer of the earth-fill dam in Pieczyska in the years 2010 2015

\begin{tabular}{|c|c|c|c|c|c|}
\hline $\begin{array}{l}\text { Piezome- } \\
\text { ter name }\end{array}$ & $\begin{array}{l}\text { Number } \\
\text { of rela- } \\
\text { tionships }\end{array}$ & $\begin{array}{l}\text { Piezome- } \\
\text { ter name }\end{array}$ & $\begin{array}{l}\text { Number } \\
\text { of rela- } \\
\text { tionships }\end{array}$ & $\begin{array}{l}\text { Piezome- } \\
\text { ter name }\end{array}$ & $\begin{array}{l}\text { Number } \\
\text { of rela- } \\
\text { tionships }\end{array}$ \\
\hline P16A & 55 & A4D & 1 & P126 & 28 \\
\hline P16B & 9 & P7A & 61 & P140B & 2 \\
\hline P1 & 69 & P7B & 61 & $\mathrm{P} 140 \mathrm{C}$ & 46 \\
\hline P11B & 31 & P8A & 64 & P146 & 10 \\
\hline P43 & 43 & P8B & 65 & P104 & 60 \\
\hline P13B & 28 & $\mathrm{P} 8 \mathrm{C}$ & 65 & B4A & 60 \\
\hline P13Az & 58 & P9A & 67 & B5A & 67 \\
\hline P15A & 72 & P9B & 65 & P111 & 67 \\
\hline P10A & 58 & P9C & 49 & P120 & 49 \\
\hline P10B & 23 & P125 & 44 & P131 & 59 \\
\hline $\mathrm{P} 40$ & 59 & $\mathrm{P} 130$ & 46 & P141 & 69 \\
\hline P114 & 65 & P145 & 19 & P1A & 61 \\
\hline P119 & 66 & P150 & 7 & $\mathrm{RgP7}$ & 67 \\
\hline P128 & 50 & P2A & 57 & P121 & 56 \\
\hline P36 & 62 & P2B & 58 & P132 & 68 \\
\hline P38 & 68 & P3B & 62 & P117 & 65 \\
\hline PIV & 66 & P3A & 61 & P122 & 66 \\
\hline P39 & 66 & P110 & 67 & P113 & 68 \\
\hline PII & 68 & $\mathrm{P} 4 \mathrm{~A}$ & 62 & P123 & 58 \\
\hline P129 & 68 & P4B & 64 & A5A & 66 \\
\hline P138A & 6 & $\mathrm{P} 4 \mathrm{C}$ & 67 & S-5 & 54 \\
\hline P138B & 4 & P5A & 62 & P60 & 70 \\
\hline P138C & 68 & P5B & 65 & P61 & 61 \\
\hline P6A & 59 & P5C & 46 & P62 & 37 \\
\hline P6B & 57 & P116 & 62 & P63 & 7 \\
\hline $\mathrm{P} 6 \mathrm{C}$ & 58 & P124A & 0 & P64 & 0 \\
\hline X6 & 49 & P124B & 46 & & \\
\hline A4B & 60 & P124C & 45 & & \\
\hline
\end{tabular}

Source: own study.

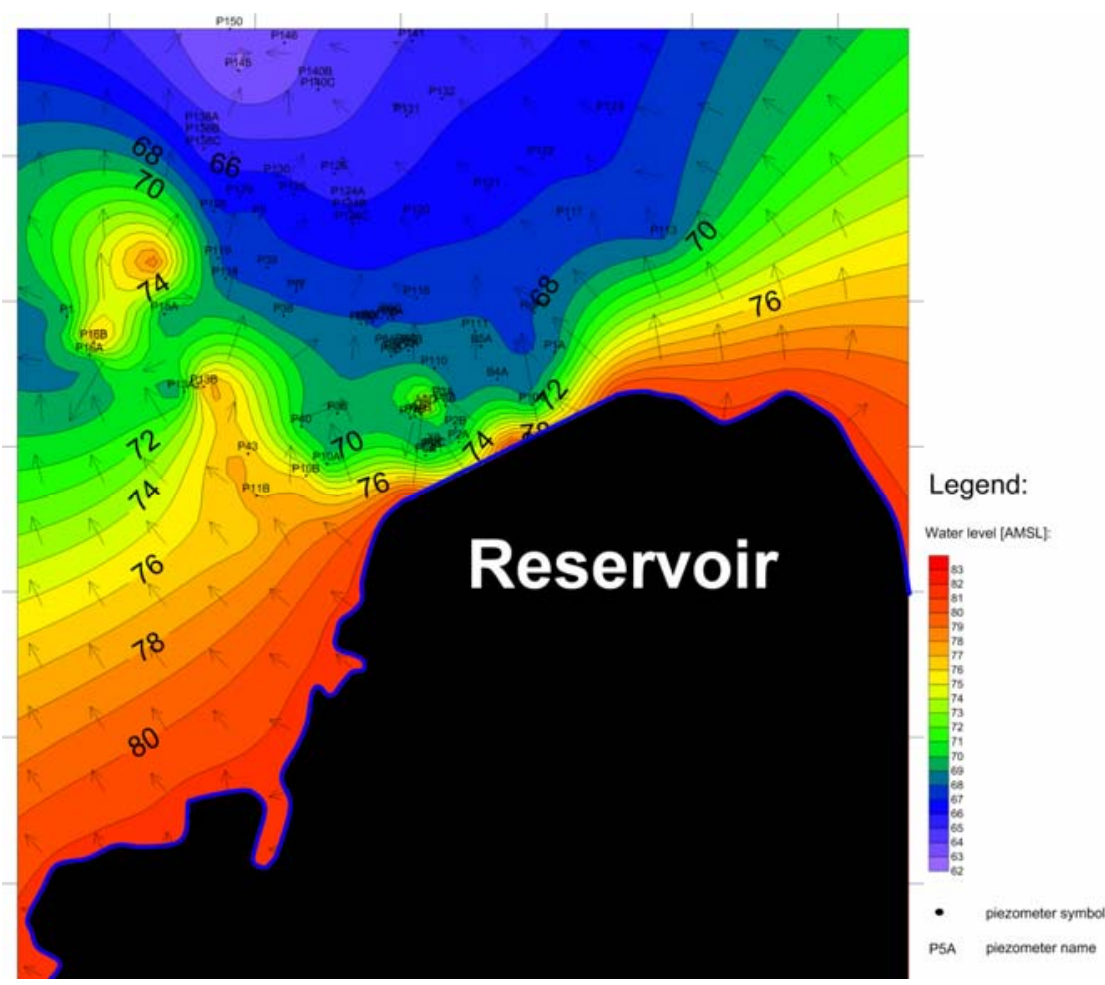

Fig. 4. The system of equipotential lines for the dam in Pieczyska in the years 2010-2015; source: own study it is possible to infer about the direction of its flow, as well as its shape and head. The equipotential lines for the analyzed dam were prepared in the demo version of Surfer 13. Figure 4 illustrates the system of the equipotential lines for the analyzed dam, which confirms that the piezometer P15A was the "source". Given the high water pressure, it can be concluded that on the left abutment of the dam there were three more source piezometers located (P16B, P13B and P64). However, the number of relationships obtained in their case did not confirm that these piezometers served as the "sources".

\section{CONCLUSIONS}

The applied method of the scalar product is the approach devoid of subjectivity, used for determining the direction and intensity of the seepage process. Proper diagnosis of this process can greatly reduce the repair costs of the dam (injections or other methods of sealing), and significantly increase the safety of the existing earth-fill dams. The main conclusions of the works carried out in the research can be formulated as follows:

1. In the case of the earth-fill dam in Pieczyska, in the years 2010-2015, two piezometers (located on the left abutment of the dam and denoted as P15A and P60) exhibited a direct hydraulic connection with the upstream water level (the scalar product approach).

2. For the studied dam, the "source" piezometer turned out to be the piezometer P15A. This fact is confirmed both by the number of connections between the individual piezometers and the resulting system of the equipotential lines for the dam.

This article does not exhaust the subject of the analysis of the phenomenon of seepage using the scalar product approach. A deeper analysis of the properties of the matrix of similarity of changes in water levels seems to be one of the promising directions for future research. Such a matrix is a symmetric matrix, because the relationship of similarity is a reflexive relationship. As every symmetric matrix, it can be diagonalized. Then, in the base of eigenvectors, eigenvalues will appear on the diagonal, and the remaining elements of the matrix will be equal to zero. The natural objective of the future research should therefore be the interpretation of the engineering significance of eigenvalues and the search of the engineering interpretation of the determined 
eigenvectors. This task seems to be an interesting scientific problem, the solution of which can contribute to a better identification and a deeper understanding of the phenomena of seepage which occur in earth-fill dams.

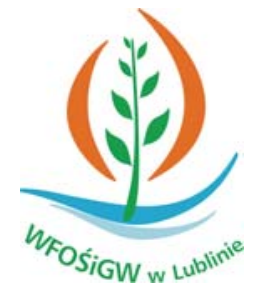

Dofinansowano ze środków Wojewódzkiego Funduszu Ochrony Środowiska i Gospodarki Wodnej w Lublinie Cofinanced by Voivodeship Fund for Environmental Protection and Water Management in Lublin

\section{REFERENCES}

BYCZKowsKi A. 1999. Hydrologia [Hydrology]. T. 1. $2^{\text {nd }}$ ed. Warszawa. Wydaw. SGGW. ISBN 83-7244-068-9 pp. 416.

Czaja J., Preweda E. 2000. Analiza statystyczna zmiennej losowej wielowymiarowej $\mathrm{w}$ aspekcie korelacji i predykcji [Statistical analysis of multi-dimensional random variable in terms of correlation and prediction]. Geodezja. No. 2 p. 129-145.

DEPCZYŃSKI W., SZAMOWSKI A. 1999. Budowle i zbiorniki wodne [Structures and water reservoirs]. $2^{\text {nd }}$ ed. Warszawa. Ofic. Wydaw. PW. ISBN 83-87012-66-1 pp. 229.

FELLER W. 2006. Wstęp do rachunku prawdopodobieństwa [Introduction to probability]. T. 1. $6^{\text {th }}$ ed. Warszawa. Wydaw. Nauk. PWN. ISBN 83-01-14684-2 pp. 456.

JiE Y., Wen Y., DenG G., ChEN R., Ze-PING X. 2012. Impact of soil deformation on phreatic line in earth-fill dams. Computers \& Geosciences. No 46 p. 44-50.

KLEDYŃSKI Z. 2006. Remonty budowli wodnych [Repairs of water structures]. $1^{\text {st }}$ ed. Warszawa. Ofic. Wydaw. PW. ISBN 83-7207-642-1 pp. 212.

KLEDYŃSKI Z. 2011a. Monitoring i diagnostyka budowli hydrotechnicznych [Monitoring and diagnostics of hydraulic structures]. Nowoczesne Budownictwo Inżynieryjne. Nr 2 p. $54-61$.

KLEDYŃSKI Z. 2011b. Monitoring i diagnostyka budowli hydrotechnicznych [Monitoring and diagnostics of hydraulic structures]. Nowoczesne Budownictwo Inżynieryjne. $\mathrm{Nr} 3$ p. 36-38.

LACH S. 2016a. Wykrywanie oraz eliminacja obserwacji odstających w hydrotechnice. W: Badania i rozwój młodych naukowców w Polsce: woda i ścieki [Detection and elimination of outliers in hydrotechnics. In: Research and development of young scientists in Poland: water and waste water]. Ed. J. Leśny, J. Nyćkowiak. Poznań. Wydaw. Młodzi Naukowcy p. 38-46.

LACH S. 2016b. Wykrywanie oraz eliminacja błędów grubych w pomiarach piezometrycznych dla zapory Koronowo w latach 2010-2015. W: Badania i rozwój młodych naukowców w Polsce: woda i ścieki [Detection and elimination of outliers in the measurement of piezometers located in Koronowo dam in the period 2010 2015. In: Research and development of young scientists in Poland: water and waste water]. Ed. J. Leśny, J. Nyćkowiak. Poznań. Wydaw. Młodzi Naukowcy (in print).

ŁOMNICKI A. 2014. Wprowadzenie do statystyki dla przyrodników [Introduction to statistics for naturalists]. $5^{\text {th }}$ ed. Warszawa. Wydaw. Nauk. PWN. ISBN 978-8301-17948-9 pp. 280.

MOLSKI T. 2012. Ziemne budowle hydrotechniczne i ich podłoże w warunkach filtracji naporowej [Earth-fill hydraulic structures and their foundation in pressured filtration conditions]. Infrastruktura i Ekologia Terenów Wiejskich. No 3/III p. 54-61.

NowAK R. 2002. Statystyka dla fizyków [Statistics for physicists]. $1^{\text {st }}$ ed. Warszawa. Wydaw. Nauk. PWN. ISBN 83-01-13899-8 pp. 127.

OpYRChAE L., LACH S. 2014. Badanie kierunku filtracji w zaporach ziemnych $\mathrm{z}$ wykorzystaniem metody iloczynu skalarnego. W: Zagrożenia jakości wód powierzchniowych i metody działan ochronnych [Testing the direction of seepage through the earth-fill dams using the scalar product method. In: Threats to the quality of surface water and methods of conservation practices]. Ed. G. Mazurkiewicz-Boroń, B. Marczewska. Lublin. Wydaw. KUL p. 289-300.

Opyrchat L., Selerski S., Stachurski K. 2007. Nowe metody badania kierunku filtracji [New methods for testing the direction of seepage]. XII Międzynarodowa Konferencja Technicznej Kontroli Zapór. Ed. A. Wita. Warszawa. IMGW p. 224-231.

SoBCZYK M. 2004. Statystyka [Statistics]. $4^{\text {th }}$ ed. Warszawa. Wydaw. Nauk. PWN. ISBN 83-01-14134-4 pp. 376.

Ustawa z dnia 7 lipca 1994 Prawo budowlane [Construction Law of 7 July 1994]. Dz.U. 1994. Nr 89, item 414, as amended.

WiŁUN Z. 2001. Zarys geotechniki [Geotechnical outline]. $5^{\text {th }}$ ed. Warszawa. WKiE. ISBN 83-206-1354-X pp. 723.

YuAn S., Zhong H. 2016. Three dimensional analysis of unconfined seepage in earth dams by the weak form quadrature element method. Journal of Hydrology. No 533 p. $403-411$.

\section{Stanisław LACH, Leszek OPYRCHAL}

\section{Wykorzystanie zmodyfikowanej metody iloczynu skalarnego do badania kierunku filtracji w zaporze ziemnej w Pieczyskach}

\section{STRESZCZENIE}

Obecnie w wielu istniejących zaporach coraz wyraźniej uwidaczniają się problemy związane z rozwojem zjawisk filtracji. Z tego powodu występuje stała konieczność doskonalenia istniejących oraz rozwijania nowych metod określania kierunków i intensywności rozwoju procesów filtracji występującej w zaporach ziemnych i ich 
podłożach. Analizowana zapora znajduje się w miejscowości Pieczyska w woj. kujawsko-pomorskim w 49,115 km biegu rzeki Brdy. Zamyka ona zlewnię o powierzchni $4109 \mathrm{~km}^{2}$. Celem artykułu jest weryfikacja nieinwazyjnej oraz pozbawionej subiektywizmu metody badania kierunku filtracji w zaporach ziemnych z wykorzystaniem zmodyfikowanej metody iloczynu skalarnego, pozwalającej na określenie kierunku i intensywności procesu filtracji. Prawidłowe rozpoznanie tego procesu umożliwia znaczne obniżenie kosztów remontu zapory (zastrzyków lub innych sposobów uszczelniania) oraz istotnie zwiększa bezpieczeństwo funkcjonowania istniejących zapór ziemnych. W przypadku zapory w Pieczyskach w latach 2010-2015 w dwóch piezometrach (zlokalizowane na lewym przyczółku zapory i oznaczone symbolami P15A oraz P60) stwierdzono bezpośrednie połączenie hydrauliczne z wodą górną (metoda iloczynu skalarnego). Dla badanej zapory piezometrem „źródłem” (do którego wszystkie piezometry w jego otoczeniu wykazywały podobieństwo zmian stanów wody) okazał się piezometr P15A. Fakt ten potwierdziła zarówno liczba powiązań między poszczególnymi piezometrami, jak i uzyskany układ hydroizohips w zaporze.

Słowa kluczowe: bezpieczeństwo obiektów hydrotechnicznych, iloczyn skalarny, monitoring, piezometry, zapory ziemne 